\title{
OVARIAN SARCOMA IN CHILDREN
}

\author{
BY \\ ROBERT GITTINS, M.D., M.R.C.P., D.T.M. \& H., \\ and \\ J. C. HAWKSLEY, M.D., M.R.C.P. \\ (From the Children's Hospital, Birmingham.)
}

In a communication shortly to be published* we are recording a case of bilateral ovarian neoplasms in an infant with generalized reticuloendotheliosis and monocytic leukæmia. The histology of the ovaries showed the tumours to be endotheliomata. The following were the chief features of this case.

M. D., aged 1 year, was admitted for wasting, under Dr. Smellie, to the Birmingham Children's Hospital. Bilateral, smooth, freely movable tumours, the size of cocoanuts, were discovered occupying the iliac fossæ, and regarded as ovarian sarcomata. There were no general signs of ovarian dysfunction. The tumours were removed by Mr. Scott Mason. After initial improvement the child's condition began to deteriorate, and metastases were suspected. A blood count just before death revealed leukæmia of histiocytic type. No metastases were found at autopsy, but widespread reticulo-endotheliosis was found. Re-examination of the ovarian tumours revealed a reticulo-endotheliomatous structure. The case was therefore one of bilateral ovarian endothelioma with generalized reticulo-endotheliomatosis and monocytic (histiocytic) leukæmia.

We have been unable to find any other precisely similar case in the literature. We have, therefore, taken the opportunity of reviewing the literature of ovarian sarcoma in infancy, excluding our own case in the category of this disease in enumerating the cases up to date. So closely do such rare tumours as endotheliomata mimic sarcomata that clinical differentiation appears to be impossible, while, though histological differences are present, these are so relatively slight that such processes have been termed reticulum sarcomata by some observers. Owing to these closely similar clinical and pathological features, it appears advisable at present to consider them within the classification of ovarian sarcomata for clinical purposes.

Clinical manifestations.-The clinical manifestations of ovarian sarcoma in children can with advantage be discussed under the following four headings :-

1. Changes due to presence of the tumour.

2. Changes due to the toxic effects of the tumour.

3. Changes due to disturbances of endocrine balance.

4. Changes due to metastasis.

* J. Path. and Bact., Edinburgh, 1933, January. 
1. The commonest manifestation in ovarian sarcoma in children is the actual presence of an abdominal or abdomino-pelvic mass. The presence of this mass may be discovered accidentally by doctor, parents or child, it may cause local prominence of the overlying abdominal wall, or it may be first looked for owing to the occurrence of pain, either within the tumour or from the interference with neighbouring structures. When felt it is as a rule freely movable and situated in the lower abdomen on one side or the other, or in bilateral cases both sides. The surface is as a rule slightly nodular. Tenderness of the mass may be apparent; a number of the cases showing this have undergone softening or become twisted. Free fluid within the peritoneal cavity is commonly found. Cases are on record in which the tumour has been large enough to cause respiratory embarrassment and cyanosis, while at a late stage the mass may be more or less fixed by infiltration of its surroundings. In a few cases an antecedent history of a blow has been noted. Scheffey ${ }^{1}$ questions if this was the cause rather than the means of bringing the child under observation. In one case recorded by Koster $^{2}$ the tumour had ruptured, and pieces were found lying free within the peritoneal cavity.

Interference with the other abdominal organs has often been noted, resulting in diarrhœa, constipation, vomiting, urinary disturbance and acute intestinal obstruction, for which latter condition more than one case has been operated upon.

By examination per rectum the tumour can often be felt bimanually, and a vaginal examination will sometimes reveal its attachment to the adnexa.

2. As in other malignant tumours, certain constitutional disturbances are apt to occur in this condition. Amongst those most commonly recorded are variable degrees of rise in temperature, listlessness, irritability and thirst. A secondary anæmia is often present. Changes in the leukocyte count are less constant. One case recorded by Bushnell ${ }^{3}$ suffered from epistaxis and purpura, and showed a lymphocytic count which made him regard the case as one of lymphocytic leukæmia.

3. Of great interest and diagnostic importance, are signs of disturbance of the endocrine balance. Two definite types are recorded, one of sexual precocity, and the other of a failure to mature of the sex organs. The former, as would be anticipated, is found before the usual onset of puberty, and the latter after. Sexual hyperfunction is shown by a combination of the following signs:-Precocious menstruation, enlargement of the breasts, development of pubic and axillary hair, alteration in voice (only one case recorded), precocious development of the external genitalia, and enlargement of the uterus. These symptoms may all be found in tumours of the ovary apart from sarcoma, and also in tumours of other organs such as the pituitary body, pineal body and suprarenal glands. In cases associated with delayed puberty the menstrual function is delayed or absent, the secondary sexual characteristics fail to develop, growth is often retarded and mental development impaired. 
4. Metastases are as a rule relatively late manifestations and may occur either by lymphatic spread, through the blood-stream, or by being scattered over the peritoneal cavity.

Our case of bilateral ovarian endotheliomata had but one definite sign, the most common; namely, the presence of freely movable tumours on each side in the pelvis and lower abdomen. These were accompanied by anorexia and irritability, and with anæmia which later developed into leukæmia.

Recorded cases.-The youngest recorded case of sarcoma of the ovary was found by Doran $^{4}$ in a premature infant born after seven months' gestation, who lived only a few minutes after birth. The condition was bilateral. Scheffey ${ }^{1}$ has collected all the cases of ovarian sarcoma up to and including 20 years of age, to the year 1924. His total of 118 cases includes eight under the age of two, of which seven were unilateral and one (Doran's case) bilateral. Since his paper Bates and Sincerbeaux ${ }^{5}$ have published a case of bilateral sarcoma of the ovary in an infant of ten months. We have not been able to trace any other cases under the age of two years, which leaves a total of ten cases, seven unilateral and three bilateral.

In order to bring Scheffey's list up to date we have collected all the published cases of ovarian sarcoma occurring under the age of 21 since his paper in 1925. These will be briefly discussed. They number 13 all told.

Cases 1, 2, 3, 4.-Four cases under the age of twenty-one years were published by Massazza ${ }^{6}$ in 1925, with other cases in older women. The first was in a patient of 20 and was right-sided, the second in a woman of 19 was left-sided, the third was in a woman of 19 and was on the right side, whilst the fourth was on the right side of the patient, who was 19 years old. The fourth case seems to have been doubtful as its histology was suggestive of carcinoma.

Case 5. - This case published by Koster ${ }^{2}$ in 1925 is the only instance recorded in which spontaneous rupture occurred.* Both ovaries were implicated and both had broken down, their pieces lying free in the peritoneal cavity. Secondary metastasis had occurred, and the patient went downhill rapidly after operation. No morbid histology is appended in the communication.

Case 6.-A girl of 15 years published in 1927 by Corlette $^{7}$.

Case 7.-Recorded by Atzerodt ${ }^{8}$ in 1927. The tumour affected the right ovary and was present in a girl of 18 years.

Case 8.-Described by Southam ${ }^{9}$ in 1928 : was right-sided and occurred in a child of 2 years 10 months. Sexual precocity was a predominant feature.

Case 9.-Recorded by Brown and $O^{\prime} K^{\prime} e^{10} e^{10}$ in 1928. Bilateral ovarian lymphosarcoma in a girl of 16, with metastases in breast and gums.

Gase 10.-Published by Wenger ${ }^{11}$ in 1930 occurred in a child of two and half years.

Case 11.-Jaisohn' ${ }^{12}$ case published in 1930. This occurred in a child of eight years and caused acute intestinal obstruction. The tumour was left-sided.

* While in the press, another example of rupture of an ovarian sarcoma in a child has been privately communicated to us by Dr. Van Buren and Dr. Naz. The case will be published by them later. 
Chart I shows the age incidence of ovarian sarcoma according to the available statistics up to 20 years of age. There must be very many unpublished cases, but from the evidence of those available, there would appear to be a rise in frequency after puberty. In a few of the records the ages are not stated, the cases merely being recorded as occurring in childhood. 
Varieties.-Ewing ${ }^{16}$ regards ovarian sarcoma as a comparatively rare tumour and quotes Kroemer that it accounts for 5 per cent. of all neoplasms of the ovary. There are several histological varieties; the round-cell type is rare and met with in young subjects; tumours may show spindle and larger cells, even with some alveolar arrangement. Several observers have recorded giant cells, as well as considerable variation in the size of cells (Atzerodt ${ }^{8}$, $\mathrm{Jaisohn}^{12}$ ); Massazza ${ }^{6}$ reported two cases of spindle-cell sarcoma, unusual in that no mitoses were found. Manzi ${ }^{17}$ described a stroma of fine fibrils spreading into the parenchyma of the tumours from the larger blood vessels, but without any vascular endothelial or adventitial proliferation. Several of Massazza's cases showed large cells with such a distribution of the fine stroma that an alveolar arrangement was produced and carcinoma simulated; his fifth case appears from his description more likely to be a carcinoma.

Probably many tumours showing indifferent types of cells are teratomatous. Smith and Motley ${ }^{18}$ described such a type occurring as bilateral tumours removed by operation from a child aged three; they foretold recurrence, which prophecy was fulfilled five months later, when abdominal masses had developed. Histologically there were solid masses of cells with practically no intercellular stroma, and in places remains of tubules; the cells were very immature and no outer cell wall could be made out. Their report is especially interesting in view of the authors' case (which showed monocytic leukæmia) as a blood count was done: there was no abnormality in the differential count.

Foerster $^{19}$ recorded a unilateral round-celled sarcoma in a child aged four and a half, in whom metastases occurred after operation. Southam's ${ }^{9}$ patient, aged two years and ten months, showed a small round-cell sarcoma. Malins's ${ }^{20}$ case was a cystic sarcoma in a girl aged nine. Page's ${ }^{21}$ case of fibro-sarcoma in a child aged six recovered, after operation; he believed it to be the youngest case recovering after ovariotomy for sarcoma. Wenger ${ }^{11}$ described his case as an adeno-sarcoma. Hayd's ${ }^{22}$ report of a bilateral sarcoma in a child aged five years gave histological details: rather large round cells with deeply staining vesicular nuclei and many karyokinetic figures; great tendency to hæmorrhagic infiltrations and nẹcrosis of cells; groups of cells separated by connective tissue stroma, with numerous large spindle cells scattered in the stroma. In Higgins's ${ }^{23}$ three cases, round cells predominated, though there was some mixture of spindle cells; the ages of the patients were five, seven and ten years. The patient of Bates and Sincerbeaux ${ }^{5}$ was almost of the same age as our case of ovarian endotheliomata, and showed a spindle-celled sarcoma; death occurred in five days after operation.

Endothelioma of the ovary was first described by Leopold in 1874, who considered that it was probably derived from lymphatic endothelium. Pick recognizes three types: (1) whorls or rows of cells; (2) cell groups resembling adenoma and carcinoma; (3) diffuse masses resembling sarcoma. The 
present authors' case fell into Class 3. A review of cases of ovarian endotheliomata, together with histological details will be included in their report. As previously recalled, ovarian endotheliomata are clinically indistinguishable from sarcomata and are differentiated only by histological details.

Blood changes.-Fortunately blood counts have been recorded in a few of these cases; these are interesting in view of the hæmatological importance of our case. P. Jaisohn's ${ }^{12}$ patient was aged eight years, and showed round, spindle, large spheroidal and giant cells (vide Ewing); there was slight anæmia (red cells 3,670,000, hæmoglobin 68 per cent., white cells 9,850 , with no abnormality differentially).

Bushnell's ${ }^{3}$ most interesting case of a young woman, on the other hand, did show some disturbance in the differential white-cell count. This was a case of bilateral round-cell sarcoma; epistaxis and a purpuric rash were observed. The hæmoglobin was down to 50 per cent., red cells $2,976,000$, white cells raised to 13,400 ; differentially there were $66 \cdot 4$ per cent. lymphocytes with 12.6 per cent. hyaline cells and $3 \cdot 4$ per cent. myelocytes. Bushnell concluded that the blood showed a leukæmia of mixed cell type; but, on account of the absence of any number of immature cells of the lymphoblast type and the well recognized occurrence of lymphatic cell reactions, we feel that this diagnosis, hæmatologically, is open to some doubt, though we admit that the occurrence of epistaxis and a purpuric rash is very strong clinical evidence in favour of it. This case resembles the authors' in being bilateral, in the lymphatic reaction, in an increase of monocytes; but differs from it in the age, in the occurrence of metastases, and in having a hæmoglobin content much higher than is usual in the later stages of leukæmia. Koster ${ }^{2}$ records a white count with secondary anæmia. As far as we are aware, there is no other recorded case of ovarian sarcoma or endothelioma complicated by leukæmia, and the type of leukæmia renders it unique.

\section{Summary.}

1. The literature on ovarian sarcoma relating to cases occurring up to and including the age of 20 has been reviewed.

2. L. C. Scheffey collected in 1925 all the cases of ovarian sarcoma up to this age; his total was 118 cases.

3. Thirteen cases have been reported since the date of Scheffey's paper, and these have been briefly reviewed.

4. The clinical and histological features as revealed by all these cases have been set forth.

5. The frequency of ovarian sarcoma at different ages up to 21 has been graphically represented.

We have pleasure in thanking Dr. Smellie for permission to use the records of the case quoted, and the Librarian of the Royal Society of Medicine for valuable help with references. 


\section{REFERENCES.}

1. Scheffey, L. C., Am. J. Obst. Gynec., St. Louis, 1925, IX, 490.

2. Koster, H., Ibid., 1925, X, 716.

3. Bushnell, F. G., J. Path. \& Bact., Edinb., 1907-8, XII, 126.

4. Doran, A., Trans. Path. Soc. London, Lond., 1889, XL, 200.

5. Bates, A. K., \& Sincerbeaux, G., J. Am. Med. Ass., Chicago, 1931, XCVI, 2031.

6. Massazza, M., Ann. di ostet. e ginec., Milan, 1925, XLVII, 469.

7. Corlette, C. E., Med. J. Australia, Sydney, 1927, ii, 684.

8. Atzerodt, K., Monatschr. f. Geburtsh. u. Gynäk., Berlin, 1927, LXXVI, 282.

9. Southam, A. H., Brit. Med. J., Lond., 1928, i, 661.

10. Brown, J. B., \& O'Keefe, C. D., Ann. Surg., Philad., 1928, LXXXVII, 467.

11. Wenger, H. L., Arch. Pediat., N.Y., 1930, XLVII, 736.

12. Jaisohn, P., J. Am. Med. Ass., Chicago, 1930, XCV, 1097.

13. Bland Sutton, J., Surg. Dis. of Ovaries and Fall. Tubes, London, 1896.

14. Hubert, Neber Ovarial Gerchweiste bei Kinderheit Dissert Giessen, 1901.

15. Wiel, H. I., Bull. John Hopkins Hosp., Balt., 1905, XVI, 102.

16. Ewing, J., Neoplastic Diseases, Philad., 1922, 260.

17. Manzi, L., Arch. di ost. e gynec., Naples, 1927, XIV, 534.

18. Smith, F. H., \& Motley, J. C., Surg. Gynec. Obst., Chicago, 1915, XX, 419.

19. Foerster, F., Am. J. Obst. \& Gynec., St. Louis, 1895, XXXI, 80.

20. Malins, E., Lancet, Lond., 1890, i, 1174.

21. Page, Brit. Med. J., Lond., 1890, ii, 1363.

22. Hayd, H. E., Am. J. Obst. \& Gynec., St. Louis, 1918, LVIII, 764.

23. Higgins, T. T., Brit. J. Child. Dis., Lond., 1915, XII, 161. 